\title{
PENGGUNAAN DRONE PADA PELIPUTAN BERITA TELEVISI (PERSPEKTIF WARTAWAN TELEVISI TERHADAP ETIKA PELIPUTAN MENGGUNAKAN DRONE)
}

\author{
Moehammad Gafar Yoedtadi \\ Fakultas Ilmu Komunikasi Universitas Tarumanaga \\ gafary@fikom.untar.ac.id
}

Masuk :15-04-2019, revisi: 09-09-2019, diterima untuk diterbitkan : 09-09-2019

\begin{abstract}
ABSTRAK
Saat ini pesawat drone telah menjadi perlengkapan wajib dalam peliputan berita. Pesawat drone memberikan kemudahan dan penghematan bagi media pemberitaan untuk mengambil gambar dengan sudut pengambilan dari angkasa. Dengan drone media massa, terutama televisi dapat memperkaya visual dalam beritanya. Namun dengan segala kelebihannya, penggunaan pesawat drone tetap harus mempertimbangkan etika jurnalistik. Antara lain persoalan privasi dan izin peliputan. Penelitian ini hendak menggali perspektif wartawan terhadap etika jurnalistik ketika melakukan peliputan dengan memanfaatkan pesawat drone. Penelitian ini menggunakan perspektif kualitatif dengan metode fenomenologi. Penelitian ini melibatkan empat orang wartawan drone (drone journalist) dari dua stasiun televisi. Wartawan yang dapat mengemudikan drone belum banyak. Masing-masing televisi hanya memiliki empat orang wartawan. Dari empat wartawan drone, peneliti mengambil partisipan dua orang wartawan drone yang telah bersertifikat dan berpengalaman pada masing-masing televisi. Hasil penelitian menunjukkan bahwa tidak semua wartawan drone memahami dengan benar etika peliputan menggunakan drone. Tuntutan tugas untuk mendapatkan gambar yang bagus menyebabkan para wartawaterkadang mengabaikan etika peliputan drone.
\end{abstract}

Kata kunci: Wartawan drone, Etika Peliputan, Berita Televisi

\section{ABSTRACT}

Currently, drones have become a mandatory equipment in news coverage. Drones provide convenience and cost savings for the media to take bird eye pictures. With drones, mass media, especially television can enrich the visual aspect of their news. However, with all its advantages, the use of drones must still consider journalistic ethics such as privacy issues and permission to report among other things. This research is aimed to explore the perspective of journalists toward the journalism ethics on television news coverage using drone technology. This research used qualitative approach with phenomenology method. This research involved four drone journalists from two television stations. Not many reporters can control a drone, each television station has four journalists who can do so. From the four drone reporters, the researchers took two certified and experienced drone reporters from each television station as participants. The result shows that not all drone reporters are aware about the ethics of drone usage on news coverage. The demand to obtain good footage causes drone reporters to ignore journalism ethics on drone use.

Keywords: drone journalism, journalism ethics, television news

\section{PENDAHULUAN \\ Latar Belakang}

Pemanfaatan pesawat drone untuk pengambilan gambar berupa foto atau video oleh media massa telah menjadi tren akhir-akhir ini. Kelebihan pesawat drone adalah dapat memberikan sudut pengambilan gambar yang tidak dimungkinkan dilakukan sebelumnya. Drone seolah memberikan akses bagi wartawan untuk terbang ke langit (Jarvis, 2014). Bagi wartawan televisi penggunaan pesawat drone dapat memberikan pengaayaan visual dalam sebuah laporan jurnalistik. Sudut pengambilan gambar drone dari angkasa akan membantu khalayak dalam memahami sebuah berita (Charmberlain, 2017). Peliputan di medan berbahaya seperti perang, kerusuhan sosial, peliputan bencana, akan jauh lebih aman jika menggunakan pesawat drone (Corcoran, 2014). Model peliputan investigasi yang membutuhkan penyamaran juga sangat terbantu dengan pesawat drone untuk mengambil gambar praktik-praktik kejahatan yang disembunyikan (Gibb, 2011). 
Pesawat drone atau pesawat udara tanpa awak/unmaned aerial vehichel (UAV) pada awalnya banyak digunakan untuk melayani industri pertahanan. Fungsinya antara lain untuk mengumpulkan informasi tentang gerak gerik tentara lawan dan umumnya untuk misi militer yang beroperasi dari jarak jauh (Gibb, 2011). Ide awal penggunaan UAV di medan perang dapat dilacak dari Perang Sipil Amerika dan Perang Dunia I, di mana balon udara digunakan sebagai target latihan tembak dan kemudian digunakan sebagai alat pembawa bom (Ntalakas et al, 2017). Pada perang modern seperti halnya keterlibatan AS di Afganistan, drone digunakan sebagai pesawat mata-mata dan wahana peluncur misil (Corcoran, 2014; Tremayne, 2014).

Perkembangan selanjutnya drone digunakan untuk kepentingan peliputan berita dan dikenal dengan istilah drone journalism (Tremayne, 2013; Ntalakas et al, 2017). Sebelum pesawat drone dipergunakan secara luas, stasiun televisi harus mengeluarkan biaya yang cukup besar untuk menyewa pesawat terbang atau helikopter dalam melakukan pengamatan dan pengambilan gambar dari udara. Tak salah jika hadirnya pesawat drone memberi kemudahan dan penghematan demikian besar dalam hal peliputan (Gibb, 2011; Curry, 2013).

Namun hal penting yang harus dipertimbangkan dalam penggunaan pesawat drone dalam peliputan berita adalah faktor etika jurnalistik. Pasal 2 Kode Etik Jurnalistik menyebutkan: "Wartawan Indonesia menempuh cara-cara profesional dalam melaksanakan tugas jurnalistik". Cara-cara profesional yang dimaksud dalam Kode Etik Jurnalistik salah satunya adalah menunjukkan identitas diri kepada narasumber dan menghormati hak privasi masyarakat. Tak dapat dipungkiri, dalam peliputan dengan teknologi drone, seringkali wartawan tidak mempertimbangkan kedua hal tersebut. Misalnya menerbangkan drone untuk mengambil gambar di suatu area dilakukan tanpa izin terlebih dulu. Selain itu batas ruang publik dan ruang privat dalam peliputan menggunakan drone, sering kali sulit dipetakan. Sehingga pelanggaran terhadap privasi masyarakat besar kemungkinan dapat terjadi.

Culver (2014) memaparkan empat hal yang perlu dipertimbangkan dari sisi etika jurnalistik ketika media memanfaatkan drone untuk peliputan berita. 1) Safety. Pertimbangan terhadap keselamatan orang-orang yang berada di bawah lintasan terbang drone. Di luar dimensi hukum, terdapat pertanyaan etis apakah risiko terhadap keselamatan masyarakat melebihi kepentingan peliputan? 2) Accuracy and Context. Peliputan drone dapat menghapus fakta dari konteks peristiwa. Contoh: Foto atau video unjuk rasa yang diambil menggunakan drone yang terbang tinggi tidak menentukankan seberapa besar protes yang dikemukakan para pengunjuk rasa. 3) Privacy. Persoalan terbesar dari peliputan menggunakan drone adalah pelanggaran privasi. Tidak sedikit masyarakat yang terganggu ketika ada drone terbang di atasnya dan mengambil gambar. Harus dihindari model peliputan yang mengarah pada drone paparazzi. 4) Conflic of interest. Media tidak boleh melakukan pengambilan gambar dengan drone di luar keperluan peliputan. Media tidak dapat menyerahkan hasil peliputan menggunakan drone untuk kepentingan di luar berita.

Sementara Professional Society of Drone Journalist, organisasi yang memiliki 4000 anggota drone journalist di seluruh dunia telah merumuskan kode etik dalam peliputan berita menggunakan drone (The Daily Octagon, 2015):

- Penggunaan drone harus mematuhi kode etik jurnalistik.

- Penggunaan drone harus mematuhi peraturan yang berlaku, karena tidak semua tempat bisa menjadi area penerbangan drone.

- Perekaman dengan drone harus menghormati privasi orang lain.

- Nilai berita harus sepadan dengan risiko penggunaan drone yang mungkin saja berakibat celaka di sekitar area penerbangan. 
- Pilot drone harus berpengalaman dan terlatih menerbangkan drone atas dasar faktor keamanan.

\section{Rumusan Masalah}

Berdasarkan latar belakang permasalah di atas, penelitian ini dilakukan dengan tujuan untuk mengetahui perspektif wartawan dikaitkan dengan persoalan etika jurnalistik ketika melakukan peliputan menggunakan teknologi drone. Selain itu juga untuk mengetahui seberapa jauh kesadaran etika jurnalistik wartawan pengguna drone dalam peliputan dan aplikasinya di lapangan.

\section{METODE PENELITIAN}

Penelitian ini menggunakan perspektif kualitatif dengan metode fenomenologi. Penelitian kualitatif memiliki tujuan yakni untuk memahami realitas sosial dari para individu, kelompok dan budaya. Peneliti menggunakan pendekatan kualitatif untuk mengeksplorasi perilaku, tingkah laku, perspektif, perasaan dan pengalaman orang-orang dan apa yang ada dalam inti kehidupan mereka (Bungin, 2007). Studi fenomenologi merupakan sudut pandang yang fokus terhadap pengalamanpengalaman individu dan interpretasi dunia. Menurut Creswell (2012), fenomenologi digunakan peneliti untuk mencari pengalaman-pengalaman pelaku dalam menghadapi lingkungannya.

Fokus penelitian ini adalah hendak mengungkap pengalaman para wartawan dalam melakukan peliputan menggunakan drone dikaitkan dengan etika jurnalistik. Wartawan yang berpartisipasi dalam penelitian ini adalah empat orang drone journalist dari dua stasiun televisi swasta sebagai informan. Kedua stasiun televisi swasta yang dipilih merupakan dua stasiun televisi yang masuk kategori stasiun televisi dengan rating tertinggi berdasarkan Nielsen. Wartawan yang dapat mengemudikan drone belum banyak. Masing-masing televisi hanya memiliki empat orang wartawan. Dari empat wartawan drone, peneliti mengambil partisipan dua orang wartawan drone yang telah bersertifikat dan berpengalaman pada masing-masing televisi. Nama empat orang informan dan stasiun televisi tempat mereka bekerja dirahasiakan untuk menjaga kepentingan para drone journalist tersebut.

\section{HASIL DAN PEMBAHASAN}

\subsection{Memahami Peraturan}

Keempat informan mengakui memahami peraturan-peraturan yang berkaitan dengan aktivitas menerbangkan pesawat drone. Peraturan yang diterbitkan oleh Kemenhub berupa Permenhub No. PM 90 tahun 2015 tentang Pengendalian Pengoperasian Pesawat Udara Tanpa Awak di Ruang Udara yang Dilayani Indonesia, telah diberikan ketika menjalani pelatihan.

\subsection{Pelanggaran Faktor Keamanan}

Keempat informan sepakat keamanan (safety) merupakan faktor utama sebelum melakukan peliputan menggunakan drone. Faktor keamanan tertuju pada tiga subjek: (1) kemanan untuk jurnalis (operator drone), (2) keamanan untuk pesawat drone, (3) kemanan untuk masyarakat di sekitar area penerbangan. Karena itu dalam prosedur kerja menerbangkan drone, para drone journalist terlebih dulu akan mengamati kondisi lingkungan di sekitar area penerbangan. Hal yang menjadi pengamatan adalah kondisi cuaca, kondisi area penerbangan (adakah halangan seperti pohon, kabel listrik, tali layangan, gedung tinggi, kerumunan orang). Hasil pengamatan tersebut akan menjadi dasar bagi drone journalist untuk menentukan rute penerbangan dalam pengambilan gambar. 
Dari hasil wawancara mendalam terungkap para drone journalist memang mengutamakan keamanan dalam penerbangan, namun dengan tingkat pemahaman yang berbeda-beda. Contohnya, seorang drone journalist mengatakan faktor keamanan adalah hal utama, namun mengaku masih berani mengambil gambar dengan drone yang diterbangkan tepat di atas kepala orang. Tindakan ini tentu bertentangan dengan keamanan dalam penerbangan drone. Berikut penjelasan dua orang informan:

"Saya pernah baca di internet bahwa menerbangkan drone tidak boleh pas di atas kepala orang, karena resiko kalau drone rusak dan jatuh bisa kena kepala orang, tapi kebanyakan kita main di atas kepala orang, karena dituntut untuk ambil gambar yang bagus."

"Saya masih berani menerbangkan drone di atas kerumunan orang, misalnya ada demo, 10 meter di atas kepala orang, menurut saya masih aman, yang penting cuaca dan kondisi drone dalam keadaan baik."

Pelanggaran keamanan juga terjadi pada prosedur penerbangan drone. Dari hasil wawancara terungkap bahwa dalam peliputan drone seharusnya seorang drone journalist didampingi seorang asisten yang bertugas mengawasi pesawat drone saat terbang. Sementara drone journalist bertugas mengendalikan pesawat drone dan mengambil gambar. Namun dalam praktiknya sehari-hari seringkali drone journalist bekerja sendirian tanpa didampingi asisten. Praktik ini sangat membahayakan karena beban kerja drone journalist menjadi lebih berat. Akibat hanya mengandalkan satu orang dalam peliputan menggunakan drone, mereka mengakui kecelakaan berupa jatuhnya drone sering kali terjadi. Hal ini tak sesuai dengan rumusan Culver (2014) yang menempatkan faktor keamanan pada urutan pertama etika peliputan drone. Berikut penjelasan salah seorang informan:

\footnotetext{
"Shoting menggunakan drone sebenarnya harus dua orang, satu menjadi pilot sekaligus ambil gambar, satu orang menjadi asisten untuk mengawasi drone yang sedang terbang. Kalau sedang konsentrasi ambil gambar, kita sering kali tidak tahu drone dalam keadaan aman atau tidak. Cuma kantor sering kali menugaskan peliputan hanya satu orang yang pegang drone. Makanya beberapa kali drone jatuh karena menabrak atau tersangkut kabel."
}

\subsection{Pelanggaran Izin Terbang}

Masing-masing drone journalist memiliki pendapat yang berbeda mengenai permintaan izin sebelum menerbangkan drone di suatu lokasi. Pendapat pertama mengatakan, sepanjang bukan di area terlarang untuk penerbangan drone, seperti bandara, lokasi yang berdekatan dengan kegiatan Presiden dan Wakil Presiden, kedutaan besar negara-negara asing, instalasi militer maka tidak dibutuhkan izin terbang. Bahkan salah seorang drone journalist mengakui dalam prosedur kerjanya tidak pernah meminta izin, kecuali mendapat rintangan dari aparat keamanan setempat. Pendapat kedua mengatakan, masih meminta izin untuk lokasi-lokasi tertentu, seperti objek wisata dan kantor pemerintahan. Berikut pertanyaan tiga orang informan mengenai perizinan:

"Kalau lokasi-lokasi dekat bandara, dekat istana presiden, instalasi militer, dekat kedutaan sudah pasti tidak boleh menerbangkan drone. Kalau lokasi lain tidak perlu minta izin, kecuali kalau nanti ada petugas yang nanya izin, baru kita minta izin, kalau tidak ya kita terbangin aja,"

\footnotetext{
"Kalau liputan ke luar kota, lokasi seperti kantor gubernur atau objek wisata kita tetap minta izin dulu boleh apa tidak ambil gambar pakai drone."

"Kalau harus izin dulu pasti butuh waktu lama, padahal kita butuhnya cepat, biasanya kalau datang ya langsung naik saja, kecuali nanti kalau ada petugas yang mendatangi kita dan menanyakan izin.”
} 
Dalam kode etik Professional Society of Drone Journalist telah diatur bahwa penggunaan drone harus mematuhi peraturan yang berlaku, karena tidak semua tempat bisa jadi area penerbangan drone. Termasuk dalam aturan ini adalah meminta izin terlebih dulu. Persoalan izin memang menjadi dilema bagi para drone journalist terutama ketika akan meliput sebuah peristiwa seketika yang membutuhkan kecepatan dalam mengambil gambar, misalnya kecelakaan, kebakaran. Bagi drone journalist mengurus izin terlebih dulu akan menghabiskan waktu. Ignatius Haryanto, peneliti Lembaga Studi Pers dan Pembangunan berpendapat soal izin harus diatur secara proporsional terutama untuk peliputan berita. Untuk peristiwa yang sudah direncanakan drone journalist diharuskan meminta izin, namun untuk peristiwa seketika keharusan meminta izin bisa dikecualikan (Kompas, 2015). Sementara Corcoran (2015) menyarankan perlunya regulasi yang menjamin legalitas dan kebebasan bagi drone journalism, namun dengan tetap mempertimbangkan persoalan etika, privasi, safety dan security.

\subsection{Pelanggaran Privasi}

Para drone journalist mengaku memahami etika untuk menjaga privasi masyarakat ketika mengambil gambar dengan drone. Namun hal itu seringkali dilanggar karena desakan untuk mendapatkan gambar-gambar yang bagus. Dua drone journalist mengakui pernah mendapat komplain dari masyarakat yang privasinya terganggu oleh aktvitas peliputan dengan drone. Berikut pernyataan salah seorang informan mengenai privasi:

"Saya dua kali ditegur oleh warga karena tidak suka gambarnya diambil dari drone, waktu meliput di candi Prambanan, ada turis asing yang menegur minta tidak dishoting, dan waktu di danau Kalimutu drone saya dilempar batu karena ada bule yang tidak suka gambarnya diambil."

Baik Culver (2014) dan kode etik Professional Society of Drone Journalist telah menyatakan bahwa perekaman dengan drone harus menghormati privasi orang lain. Artinya seorang wartawan drone harus menanyakan terlebih dulu kepada subjek peliputan kesediaan untuk diambil gambarnya dengan drone.

\subsection{Konflik Tugas dan Etika}

Para drone journalist mengakui beberapa kali mengalami konflik antara mendahulukan tugas peliputan dengan menjaga etika peliputan. Menurut mereka, ada beberapa penugasan peliputan yang disadari oleh drone journalist berpotensi melanggar etika peliputan drone. Baik dalam hal mengabaikan keamanan, pelanggaran izin, dan menjaga privasi. Para drone journalist biasanya melakukan negosiasi dengan produser yang memberi tugas peliputan tentang potensi pelanggaran tersebut. Terkadang keberatan para drone journalist diterima dan penugasan peliputan diubah, namun ada pula penugasan peliputan tetap dilaksanakan meski berpotensi melanggar etika. Berikut pernyataan seorang informan:

\footnotetext{
"Sewaktu simpang susun Semanggi mau diresmikan, koordinator cameraman minta mengambil gambar dari atas sehingga seluruh lingkaran jembatan terlihat, dan drone terbang sampai di atas 350 meter, padahal tidak boleh drone terbang sampai lebih dari 200 meter karena akan menggangu penerbangan pesawat, helikopter tapi karena perintah akhirnya tetap saya laksanakan."

"Pernah disuruh shoting drone di markas tentara, saya sudah bilang kalau markas tentara kita tidak boleh, saya disuruh nerbangin drone sambil sembunyi biar tidak ketahuan, saya tetap tidak mau, percuma nanti dronenya ditembak."
}

Contoh yang disebutkan narasumber tersebut tidak sesuai dengan kode etik drone journalist. Pelanggaran yang berhubungan dengan faktor keamanan sebagaimana telah diatur dengan jelas pada kode etik Professional Society of Drone Journalist. 
Bagaimanapun faktor individu wartawan, baik drone journalist atau produser amat menentukan jalannya peliputan menggunakan drone. sebagaimana dipaparkan oleh Pamela Shoemaker dan Stephen D. Reese dalam teori hirarki pengaruh terhadap isi media massa (Yoedtadi \& Pribadi, 2017), bahwa satu faktor pengaruh terhadap isi media adalah pengaruh individual atau pekerja media. Aspek personalitas jurnalis akan mempengaruhi cara jurnalis memandang sebuah fakta atau peristiwa.

\subsection{Pengabaian Kelayakan Berita}

Dari hasil wawancara terungkap para drone journalist mengeluhkan tidak dipahaminya etika peliputan drone oleh pemberi tugas peliputan di televisi tempat mereka bekerja. Hal itu menempatkan para drone journalist dalam posisi sulit. Misalnya, tidak semua penugasan peliputan memiliki nilai berita yang layak untuk diliput dengan menggunakan drone. Namun tetap dilakukan karena alasan pengambilan gambar dengan drone menambah variasi gambar.

"Pernah ada perintah untuk meliput pakai drone untuk melengkapi program wawancara dengan Anis (Baswedan) di rumahnya, lokasi rumahnya banyak pohon dan kabel, saya sudah beri tahu produser berbahaya menerbangkan drone, toh gambarnya cuma rumah dari atas, tapi produser memaksa, akhirnya dronenya nyangkut dan jatuh."

Hal ini tak sesuai dengan kode etik Professional Society of Drone Journalist bahwa nilai berita harus sepadan dengan risiko penggunaan drone yang mungkin saja berakibat celaka di sekitar area penerbangan.

\section{KESIMPULAN DAN SARAN}

\section{Kesimpulan}

Para drone journalist mengakui mengetahui etika peliputan menggunakan pesawat drone. Namun dalam pratiknya, mereka sering melanggar etika peliputan drone. Pelanggaran etika dapat terjadi, pertama akibat pemahaman etika yang berbeda-beda di antara drone journalist. Kedua, terjadi konflik antara tugas peliputan dengan pelanggaran etika, yang terkadang memaksa pada drone journalist mendahulukan tugas daripada mematuhi etika peliputan drone.

\section{Saran}

Perlu dirumuskan code of coduct for drone journalism oleh Dewan Pers atau organisasi wartawan, Aliansi Jurnalis Independen (AJI), Ikatan Jurnalis Televisi Indonesia (IJTI), dan Persatuan Wartawan Indonesia (PWI). Hingga sekarang belum ada aturan dan etika peliputan menggunakan drone bagi wartawan di Indonesia. Kementerian Perhubungan memang telah meTnerbitkan Permenhub No. PM 90 tahun 2015 tentang Pengendalian Pengoperasian Pesawat Udara Tanpa Awak di Ruang Udara yang Dilayani Indonesia. Namun aturan tersebut lebih banyak mengatur pelarangan dan izin penerbangan drone di kawasan udara terlarang (prohibited area) dan kawasan udara terbatas (restricted area). Sementara aturan yang berhubungan dengan peliputan berita menggunakan pesawat drone belum ada.

\section{Ucapan Terima Kasih (Acknowledgement)}

Terimakasih disampaikan kepada semua pihak yang telah memberikan dukungan untuk pelaksanaan penelitian dengan baik.

\section{Referensi}

Bungin, B. (2007). Penelitian kualitatif komunikasi, ekonomi, kebijakanp publik, dan ilmu sosial lainnya. Jakarta: Kencana Prenada Media Group. 
Corcoran, M. (2014). Drone journalism: Newsgathering applications of unmanned aerial vehicles (UAVs) in covering conflict, civil unrest and disaster. Retrieved from https://cryptome.org/2014/03/drone-journalism.pdf

Creswell, J., W. (2012), Research design, Pendekatan kualitatif, kuantitatif dan mixed. Yogyakarta: Pustaka Pelajar.

Culver, K.B. (2014). From battlefield to newsroom: Ethical implications of drone technology in journalism. Journal of Mass Media Ethics, 29, 52-64.

Curry, Colleen. (2013). Drones eyed by paparazzi, J-school teaching reporters how to fly them. Retrieved from https://abcnews.go.com/US/drones-eyed-paparazzi-school-teachingreporters-operate/story? $\mathrm{id}=18782432$

Gibb, Al.S. (2011). Droning the story. A thesis submitted in partial fulfillment of the requiriements for the degree of master of journalism in the faculty of graduate studies The University of British Columbia. Vancouver.

Jarvis, J. (2014). The ethical debate of drone journalism: flying into the future of reporting. Retrieved from http://opensiuc.lib.siu.edu/gs_rp/475

Kompas.com. (2015). Memotret menggunakan "drone" di Indonesia harus ada izin. Retrieved from https://nasional.kompas.com/read/2015/07/28/17254691/Memotret.Menggunakan.Drone.di .Indonesia.Harus.Ada.Izin.

Ntalakas, A., Dimoulas, C., Kalliris, G., \& Veglis, A. (2017). Drone journalism: Generating immersive experiences. Journal of Media Critiques, 3(11), 187-199.

The Daily Octagon. (2015). Ulasan soal drone dalam kegiatan jurnalistik oleh komunitas pewarta. Retrieved from https://daily.oktagon.co.id/ulasan-soal-drone-dalam-kegiatan-jurnalistikoleh-komunitas-pewarta/

Tremayne, M., \& Clark, A. (2014). New perspectives from the sky: Unmanned aerial vehicles and journalism. Digital Journalism, 2(2), 232-246.

Yoedtadi, M. G., \& Pribadi, M. A. (2017). Upaya redaksi televisi menjaga objektivitas dalam pemberitaan pilkada DKI Jakarta. Jurnal Muara Ilmu Sosial, Humaniora dan Seni, 1(2), 275-285. 